https://doi.org/10.48009/2_iis_2007_488-493

\title{
IT OUTSOURCING: A KNOWLEDGE-MANAGEMENT PERSPECTIVE
}

\author{
Mohammed H. A. Tafti, Hofstra Universit, mohammed.h.tafti@hofstra.edu
}

\begin{abstract}
The transfer of all or part of information technology (IT) functions from the user organization (client) to external (vendor) organization(s), known as IT outsourcing, has recently been the subject of numerous articles. Many research studies in this area conclude that IT outsourcing provide the client organizations with several benefits. Some studies also discuss, in general terms, various risks associated with this practice. However, there is a general lack of substantial and clear indication in the literature regarding the extent of knowledge gain/loss as a result of outsourcing. On the other hand, to be an effective strategy, IT outsourcing decisions must address various issues including the risks of compromising corporate knowledge-base and human capital. The purpose of this paper is to present an analysis of the nature of knowledge transfer as a result of IT outsourcing. The paper draws from existing literature on IT outsourcing as well as knowledge management (KM).
\end{abstract}

Keywords: IT Outsourcing, Knowledge Management, Transaction Cost, Core Competency, Boundary Spanning

\section{INTRODUCTION}

Outsourcing, as a major IT and business strategy, has become a commonplace practice in recent years [9]. More and more companies are looking beyond their own

data centers and technical expertise to achieve their business objectives [19]. According to Gartner, IT outsourcing in the

four major segments of data center, network, enterprise applications, and desktop is expected to grow from $\$ 161.9$ billion in 2002 to $\$ 235.6$ billion in 2007 [25]. Offshore outsourcing (offshoring) of software development is when a company procures programming or other development processes from a supplier providing human resources that are located in a foreign country.

By signing outsourcing agreements, firms expect to reduce their overall IT costs, focus on their core competencies, and gain superior technical resources. Among all reasons to outsource, the one that has emerged as the prime reason in recent years is to gain competitive advantage through partnership by sharing information and knowledge [21, 24]. However, without a careful consideration of the issues related to the enterprise-wide IT knowledge, any gain in the above areas can be offset by a significant knowledge loss. This paper presents an analysis of IT outsourcing implications from a knowledgemanagement perspective. To set the context of this investigation, a brief review of the literature on theories/views relevant to outsourcing is presented in the following section. Next, outsourcing is discussed from a knowledge-management perspective followed by use of a KM framework that identifies three dimensions of corporate knowledge. Practical and research implications of the $\mathrm{KM}$ framework are discussed in the conclusion section.

\section{IT OUTSOURCING: THEORETICAL BACKGROUN}

In a broad context, IT outsourcing may be considered as a part of overall IT sourcing strategy and, therefore, is an extension of make-buy decision. In this sense, IT outsourcing has been utilized by various organizations as early as their use of electronic data processing (EDP) and Autocoder on IBM 1401 in late 1950's and 1960's. However, it has become a prominent option in development of application packages and contract programming in the 1970's and 1980's. Later, it has made major inroads into the areas of application development, and then enterprise-wide system integration in the 1990's [21]. While the major impetus behind early stages of IT outsourcing has been cost-savings and improvement in operational efficiency, a significant emerging motive for its recent use is building a successful strategic partnership and knowledge sharing [20, 24, 28, 35].

Several theories have been discussed in the literature to explain outsourcing from various viewpoints [11]. Following presents a brief discussion of three theories that are related to the impact of outsourcing on corporate knowledge.

Transaction Cost Theory: A firm's sourcing strategy is based on a number of factors including the cost of securing IT products and services from external sources. According to transaction cost 
theory (TCT), if the cost of monitoring, controlling, and managing a transaction with an external source is too high then the firm's reliance on internal resources, either existing or resources acquired through vertical integration, is more appropriate [13, 39].

An IT outsourcing deal requires investment in various types of assets- human capital, knowledge, and money [2]. The extent of need to invest in specific assets, both human and physical capital, that are necessary to manage, monitor, and control a transaction is called asset specificity. Asset specificity is determined by the degree to which the value of an asset is lost due to switching it to its second best use [38]. The higher the asset specificity, the higher is the transaction cost of outsourcing. Accordingly, asset specificity for acquiring knowledge is obviously higher than that of money since the needed knowledge that is, for example, acquired to control an ERP outsourcing transaction may significantly diminish in value if switched for another use such as developing Java codes. Consequently, as organizations move from outsourcing routine, structured applications to outsourcing more complex applications such as ERP, they incur a higher transaction cost. Regardless of the actual cost of ERP application development, it is more costly to manage the ERP outsourcing contract because of the need for human capital capable of creating complex contract, monitoring and controlling the work, and managing the client-vendor relationship.

Core Competency Theory: Considering the fact that resources are limited for all organizations regardless of their size, the core competency theory asserts that corporate resources are best utilized if they are allocated to those activities the organization can perform best [14, 32]. These activities are the organization's core competency and provide the organization with strategic advantage. While outsourcing non-core activities are considered in the outsourcing literature to be a plausible practice, and continue to be a significant portion of outsourcing deals, there exist a general apprehension regarding outsourcing of core activities. Although some organizations may outsource certain areas of their core competencies such as clinical trails in pharmaceutical companies [18], it is generally argued that companies should focus their limited resources on "a relatively few knowledge-based core competencies where they can develop best-in-world capabilities” [32, p. 11]. To ensure a sustained, longterm benefit of outsourcing, organizations must maintain a balance between information exchange with their outsourcing partners and safeguarding the enterprise's intellectual property and resources [40].

Boundary Spanning Theory: Organizational boundaries reflect division of labor across individuals and fields. Therefore, the nature and type of specialization, know-how, and human capital, among others, may be explained through the study of organizational boundaries. Furthermore, since organizations as open systems have flexible, penetrable boundaries, the nature and extent of interorganizational collaboration and information exchange is dependent on boundary spanning capabilities and skills of the organizations involved [10, 12]. Monge and Eisenberg [27] describe Boundary spanning as providing the communicative linkages that organizational members need to exchange information with the organizational environment.

The boundary spanning theory has mostly been used in the IT literature to explore and explain communication and collaboration among IT professionals and between IT departments with other units within the organization [16, 17, 22, 30, 34]. Pawlowski and Robey [29] have used boundary spanning to explain the knowledge broker role that explains knowledge transfer across the organizational boundaries. Results of their case study suggest that IT professionals can play a key role not merely in intra-organizational $\mathrm{KM}$, but also in transferring knowledge across organizational boundaries.

The theories discussed above, among others, provide a general context to explain both opportunities and risks of cross-boundary knowledge transfer among organizations engaging in outsourcing deals. The following section on knowledge management perspective of outsourcing will shed some light on the potential risks of knowledge loss as a result of outsourcing.

\section{KNOWLEDGE MANAGEMENT PERSPECTIVE}

The state of enterprise knowledge base generally depends on the level and quality of human capital including various networks (or communities) of experts, formally or informally created throughout the organization. Successful implementation of IT projects is largely a function of IT intellectual capital which is a subset of the corporate overall human capital [33].

IT intellectual capital cannot be simply created by putting discrete wads of IT professionals and some 
codified bodies of transferable knowledge together in a short period of time [36]. Rather, it is developed through interplay among them over time and within the context of specific corporate environment. Figure 1 shows a recent framework that identifies two dimensions of enterprise IT knowledge [37]. This paper extends the framework to include the important role of business knowledge in addition to technical IT knowledge. Therefore, the complex process of creation, use, and maintenance of IT-related knowledge involves three interrelate

Table 1: A Knowledge-Management Framework of IT Outsourcing

\begin{tabular}{|l|l|l|} 
& \multicolumn{1}{|c|}{ Company-Specific Knowledge } & \multicolumn{1}{|c|}{ General Knowledge } \\
\hline & $\begin{array}{l}\text { Factors and corporate-specific relations } \\
\text { and processes that should be considered in } \\
\text { designing the company's data warehouse. }\end{array}$ & $\begin{array}{l}\text { Knowledge of the principles and methods for } \\
\text { designing a database, given a set of user requirements } \\
\text { and business rules. }\end{array}$ \\
\hline $\begin{array}{l}\text { Human-factor considerations for designing } \\
\text { Knowledge of user interface design techniques to } \\
\text { support human-machine interface. }\end{array}$ \\
\hline $\begin{array}{l}\text { a user interface for the company's } \\
\text { employees. }\end{array}$
\end{tabular}

Source: Tafti, 2006, p. 286.

dimensions of knowledge: explicit (codified) VS tacit knowledge; specific, context-based VS general knowledge; and technical VS business knowledge. Following presents a discussion of these dimensions.

Explicit and Tacit knowledge: Several studies present knowledge management models that help mangers invest in knowledge tools, recommend formal process analysis, and describe best practices $[1,5,15]$. Two knowledge paradigms that assist in identifying states of knowledge management are the information processing and sense making models [15]. The information processing view refers to taskspecific knowledge and is oriented towards problemsolving $[8,23]$. Sense making relies on the capacity of human beings to translate information into meaning and to define problems $[6,23,26]$. The information processing view is associated with "explicit knowledge" and the sense making view is associated with "tacit knowledge" [31] More frequently, though, tacit knowledge refers to the knowledge that resides in the minds of people such as a company's employees, customers, and vendors. The explicit knowledge, on the other hand, is that which has been externalized or documented.
Context-Based and General Knowledge: Contextbased knowledge is specific to a particular tool, technology or work environment [7]. Organizationspecific knowledge, for instance, is the knowledge created and embedded in the context of a specific supply chain in the organization. An IT professional, for example, may decide on certain design aspects based on his or her knowledge of the interweaving parts of the company's operations [5]. General knowledge, on the other hand, is applicable in many different contexts and is often possessed by a large number of people, both within and outside a specific work environment. Examples of this latter type of knowledge include skills in various programming languages and database design, in general.

Technical and Business Knowledge: A critical role of IT professionals is to take an active participation in aligning IT and business strategy. This requires a combination of both technical and business knowledge [5]. Technical knowledge involves ITrelated skills such as database design and management, applications development methods, programming languages, and hardware technologies 
to name a few. Business knowledge involves business process reengineering, business relations management, human resources management, risk assessment, project management, and contract negotiation among many others. Figure 1 shows dimensions of the enterprise IT knowledge base discussed above.

By all indications, the outsourcing of knowledge work is expected to grow and even accelerate. In view of the above discussion, the knowledge work that is most likely to be outsourced is of the general and

explicit types. This involves much of the coding and maintenance functions. Some of the companyspecific, tacit knowledge work (Table 1, quadrant 1) is also being outsourced and such outsourcing is expected to grow in the near future. However, longterm implications for companies outsourcing much of their knowledge work and particularly of this latter type are significant.

\section{CONCLUSION}

Companies have often justified their outsourcing decisions on the basis of cost-benefit analyses. Although cutting cost continues to be a major impetus for IT outsourcing, it should not be the only decision criteria. All sourcing decisions must be made in light of relevant dimensions of IT knowledge environment, and should be based upon related theoretical foundations. Otherwise, any financial gain is likely to be offset by significant loss of enterprise knowledge.

Outsourcing decisions are often based on analyses that emphasize short-term, tangible costs. Intangible costs which often accrue over a longer period of time (i.e., high asset specificity discussed above), are usually not apparent right away - nor are they straight forward to quantify [4]. One important

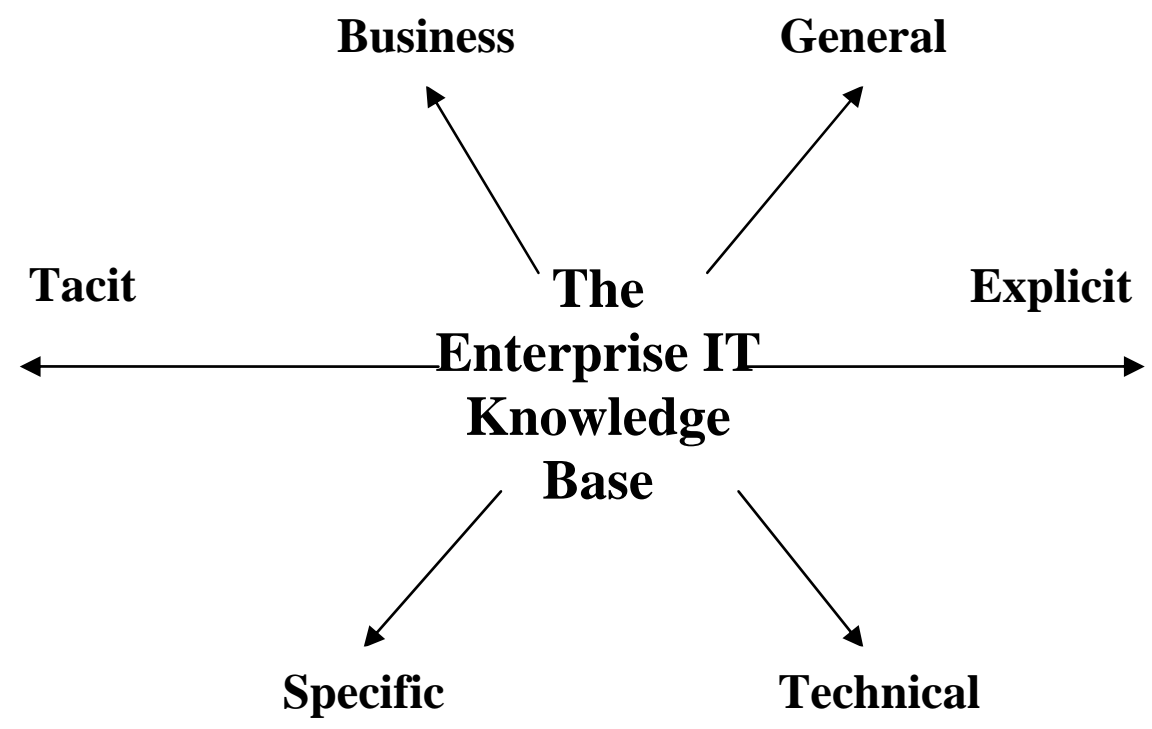

Figure 1Dimensions of Enterprise Knowledge

source of intangible costs of IT outsourcing is the loss of irreplaceable skills and knowledge particularly the context-specific, tacit knowledge. Often context-based, company-specific knowledge (core competency) is gained through many years of work in a specific organization and in teams and workgroups [3]. By working in specific work environments, individuals and teams show evidence of "learning curves". Such knowledge is specific to corporate culture and the way a firm conducts its business, and is essential in efficient design and development of business processes - particularly those processes that are cross-functional. Loss of employees with such experience as a consequence of IT outsourcing can be extremely costly for an organization.

On the other hand, when guided by the underlying theories as discussed above and based on a thorough understanding of specific dimensions of the corporate knowledge-base, a proper IT outsourcing strategy could result in considerable gains for all parties involved. Such gains are not only financial but also in terms of mutually beneficial knowledge sharing. 


\section{REFERENCES}

1. Alavi, M. \& Leidner, D. E., (2001). Review: Knowledge Management and Knowledge Management Systems: Conceptual Foundations and Research Issues, MIS Quarterly, 25(1): 107-132.

2. Aubert, B. A., Rivard, S. \& Patry, M. (2004). A Transaction Cost Model of IT Outsourcing, Information \& Management, 41(7): 921-932.

3. Argote, L. (1993). Group and Organizational Learning Curves: Individual, System, and Environmental Component, British Journal of Social Psychology, 32: 31-51.

4. Barthelemy, J. (2001). The Hidden Costs of IT Outsourcing, MIT Sloan Management Review, 42(1): 60-69.

5. Bassellier, G. and Benbasat, I, (2004). Business Competence of Information Technology Professionals: Conceptual Development and Influence on IT-Business Partnerships, MIS Quarterly, 28(4): 673-94.

6. Churchman, C. W. (1971). The Design of Inquiring Systems: Basic Concepts of Systems and Organization, Basic Books, NY.

7. Davenport, T. H. and Prusak, L. (1987). Working Knowledge: How Organizations Manage What They Know, Harvard Business School Press, Boston, MA.

8. Davenport, T.; Delong, D. W. and Beers, M.C. (1998). Successful Knowledge Management Projects, Sloan Management Review, 39(2): 4357.

9. Drucker, P. (2002). They're Not Employees, They're People, Harvard Business Review, 80(2): 71-77.

10. Fish, K. E. \& Seydel, J. (2006). Where IT Outsourcing is and Where it is Going: A Study Across Functions and Department Sizes, Journal of Computer Information Systems, 46(3): 96-103.

11. Garicano, L. Hubbard, T. N. (2003). Firms' Boundaries and the Division of Labor: Empirical Strategies, Journal of the European Economic Association, 1(2/3): 495-502.

12. Gottschalk, P. \& Solli-Saether, H. (2005). Critical Success Factors From IT Outsourcing Theories: An Empirical Study, Industrial Management \& Data Systems, 105(6): 685.702.

13. Grant, R. M. (1997). The Knowledge-Based View of the Firm: Implications for Management Practice, Long Range Planning, 30(3): 450-454.

14. Grossman, S. \& Hart, O (1986). The Costs and Benefits of Ownership: A Theory of Vertical and Lateral Integration, Journal of Political Economy, 94(4): 691.719.

15. Hamel, G., and Prahalad, C. K. (1996). Competing for the Future, Harvard Business School Press, Boston.

16. Holsapple, C. W. and Joshi, K. D. (2002). Knowledge Management: A Threefold Framework, Information Society, (18)1: 47-66.

17. Igbaria, M., \& Chidambaram, L. (1997). The Impact of Gender on Career Success of Information Systems Professionals: A Humancapital Perspective, Information Technology \& People, (10)1: 63-86.

18. John, S. (2006). Leadership and Strategic Change in Outsourcing Core Competencies: Lessons from the pharmaceutical industry, Human Systems Management, 25(2): 35-143.

19. Lacity, M. and Hirschheim, R (1993). The Information Systems Outsourcing Bandwagon, Sloan Management Review, 35(1): 73-85

20. Lee, J. N. \& Kim, Y. G. (1999). Effect of Partnership Quality on IS Outsourcing Success: Conceptual Framework and Empirical Validation, Journal of Management Information System, 15(4): 29-62.

21. Lee, J. N. (2001). The Impact of Knowledge Sharing, Organizational Capability, and Partnership Quality on IS Outsourcing Success, Information \& Management, 38(5): 323-335.

22. Lee, D. M. S.; Trauth, E. M. \& Farwell, D. (1995). Critical Skills and Knowledge Requirements of IS Professionals: A Joint Academic/Industry Investigation, MIS Quarterly, 19(3): 313-340.

23. Malhotra, Y. (2000). Knowledge Management and New Organizational Forms: A Framework for Business Model Innovation, Information Resources Management Journal, 13(1): 5-14.

24. McFarlan, F. W. \& Nolan, R. (1995), How to manage an IT outsourcing alliance, Sloan Management Review, 36(2): 9-22.

25. McFarlan, F. W. \& Delacey, B. (2004) Outsourcing IT: The Global Landscape in 2004, Harvard Business School Publishing, Article\# 9-304-104.

26. Mitroff, I., and Linstone, H. A. (1993). The Unbounded Mind: Breaking the Chains of Traditional Business Thinking. Oxford University Press, Inc., NY.

27. Monge, P. R. \& Eisenberg, E. M. (1987). Emergent Communication Networks, in Handbook of Organizational Communication: An Interdisciplinary Perspective. Jablin, F. M., Putnam, L. L., Roberts, K. H., \& Porter L. W. (Eds.), Sage Publications, Beverly Hills, CA: 304-342. 
28. Mowery, D. C., Oxley, J. E. \& Silverman, B. S. (1996) Strategic Alliances and Interfirm Knowledge Transfer, Strategic Management Journal, 17: 77-91.

29. Polanyi, M. (1967). Tacit Dimension, Routledge \& Keegan Paul, London.

30. Pawlowski, S. D. \& Robey, D. (2004). Bridging User Organizations: Knowledge Brokering and the Work of Information Technology Professionals, MIS Quarterly, 28(4): 645-672.

31. Peppard, J. (2001). Bridging the Gap Between the IS Organization and the Rest of the Business: Plotting a Route, Information Systems Journal, 11(3): 249-270.

32. Quinn, J. B. (1999). Strategic Outsourcing: Leveraging Knowledge Capabilities," Sloan Management Review, 40(4): 9-21.

33. Reich, B. H. \& Benbasat, I. (2000). Factors That Influence the Social Dimension of Alignment Between the Business and Information Technology Objectives, MIS Quarterly 24(1): 81-113.

34. Rockart, J. F., Earl, M. J., \& Ross, J. W. (1996). Eight Imperatives for the New IT Organization, Sloan Management Review, 38(A): 31-42.

35. Simonin, B. L. (1999) Ambiguity and the process of knowledge transfer in strategic alliances, Strategic Management Journal, (20)7: 595-623.

36. Stewart, T. (2001). The Wealth of Knowledge: Intellectual Capital and the Twenty-First Century Organizations. Nicholas Brealey, London.

37. Tafti, M. H. (2006). Information Systems Outsourcing: A Knowledge-Management Framework, Issues in Information Systems, 7(2): 284-288.

38. Williamson, O. E. (1981). The Modern Corporation: Origins, Evolution, Attributes, Journal of Economic Literature, 19(4): 15371568.

39. Williamson, O. E. (1985). The Economic Institutions of Capitalism, New York, Free Press.

40. Wu, F.; Li, H. Z.; Chu, L. K. \& Sculli, D. (2005). An outsourcing decision model for sustaining long-term performance, International Journal of Production Research, 43(12): 25132535

*NOTE: This research is supported by a grant from Frank G. Zarb School of Business, Hofstra University. 